\title{
Metabotropic Glutamate Receptor-Mediated Suppression of an Inward Rectifier Current Is Linked via a cGMP Cascade.
}

\author{
Don B. Dixon and David R. Copenhagen \\ Departments of Ophthalmology and Physiology, University of California, San Francisco, California 94143
}

Glutamate, the neurotransmitter released by photoreceptors, excites horizontal cells and OFF-type bipolar cells by activating ionotropic receptors. This study investigated an additional action of glutamate in which it modulates a voltage-gated ion channel in horizontal cells. We find that glutamate and APB (2-amino-4-phosphonobutyrate) produce a delayed and moderately prolonged suppression of an inward rectifier current $\left(\mathrm{IR}_{\mathrm{K}}{ }^{+}\right)$. This effect is proposed to occur via an APB-sensitive metabotropic glutamate receptor (mGluR) because common agonists for the ionotropic or APB-insensitive mGluRs are ineffective and the APB-insensitive receptor antagonist $\alpha$-methyl4-carboxyphenylglycine (MCPG) does not block the actions of glutamate or APB. 8-Br-cGMP, 1-methyl-3-isobutylxanthine (IBMX), and atrial natriuretic peptide (ANP) but not 8-Br-cAMP mimic the suppression of $\mathrm{IR}_{\mathrm{K}}{ }^{+}$. The effects of glutamate and APB are blocked by protein kinase inhibitors including $\mathrm{Rp}-8$ -
pCPT-cGMPS, $\mathrm{H}-8$, and $\mathrm{H}-7$ as well as by ATP $\gamma \mathrm{S}$. We hypothesize that the APB receptor suppresses $\mathrm{IR}_{\mathrm{K}}{ }^{+}$via upregulation of cGMP and subsequent activation of a cGMP-dependent protein kinase. This pathway is likely regulated by an ATPdependent phosphorylation. This is a novel signaling pathway for mGluRs and indicates that at least two distinct APBactivated pathways exist in the retina. Functionally, this APB receptor-mediated action found in horizontal cells would provide a means by which spatially restricted changes of glutamate, produced by local illumination of photoreceptors, could regulate $\mathrm{IR}_{\mathrm{K}}{ }^{+}$and consequently the response properties of these neurons. This would serve to adapt selectively retinal regions stimulated by small regions of the visual world.

Key words: metabotropic; inward rectifier; cGMP; retina; second messenger; glutamate
Activation of metabotropic glutamate receptors (mGluRs) can modulate ligand-gated, voltage-dependent potassium and calcium channels. Although many mGluR-linked intracellular signaling pathways have been identified in expression systems (Nakanishi, 1992; Pin and Duvoisin, 1995), it is not evident that the full repertoire of mGluR-linked pathways have been discovered. Furthermore, expression systems may exhibit multiple and possibly misleading coupling and effector mechanisms for specific mGluRs (Bockaert et al., 1993; Saugstad et al., 1994). Studies of native mGluR pathways in intact cells can be potentially more informative in this respect.

Seven of the eight known mGluR subtypes are selectively expressed in different classes of retinal neuron, suggesting a diversity of mGluR-mediated actions (Hartveit et al., 1995; Pin and Duvoisin, 1995; Koulen et al., 1996). Surprisingly, only two neuronal-specific mGluR-mediated actions on ionic channels have been characterized. In ON bipolar cells, light responses are signaled by activation of mGluR6 that reduces cGMP by upregulation of a phosphodiesterase. This leads to the closure of cGMPgated channels (Nawy and Jahr, 1990; Shiells and Falk, 1990). In ganglion cells mGluR1/5 agonists serve a modulatory role by reducing a calcium current via an $\mathrm{IP}_{3}$ pathway (Akopian and

Received June 23, 1997; revised Sept. 11, 1997; accepted Sept. 16, 1997.

This work was supported by the National Institutes of Health. Additional support was provided by Research to Prevent Blindness (D.R.C. is the recipient of a Senio Investigator Award) and That Man May See, Inc. We thank Drs. L. Jan and R. Nicoll for helpful discussions and Dr. D. Krizaj for a critical reading of this manuscript.

Correspondence should be addressed to Dr. David R. Copenhagen, Department of Ophthalmology, Box 0730, University of California, San Francisco, San Francisco, CA 94143-0730.

Dr. Dixon's present address: Department of Pharmacology, University College, London, Gower Street, London WC1E 6BT, UK.

Copyright (C) 1997 Society for Neuroscience $\quad 0270-6474 / 97 / 178945-10 \$ 05.00 / 0$
Witkovsky, 1996). Because the retina is known to adapt its restricted operating range to cover over 10 log units of light intensity, it is plausible that many more mGluR-mediated actions might be playing signaling or modulatory roles in the adaptation and/or processing of visual information.

Previous studies showed that the inwardly rectifying current $\left(\mathrm{IR}_{\mathrm{K}}{ }^{+}\right)$of horizontal cells regulates response properties of these cells and is modulated by glutamate. Tachibana (1983) demonstrated that $\mathrm{IR}_{\mathrm{K}}{ }^{+}$contributes to the resting potential of these neurons. Dong and Werblin (1995) provided evidence that $\mathrm{IR}_{\mathrm{K}}{ }^{+}$ speeds the onset of the hyperpolarizing light responses in these neurons. In photoreceptors, current flow through inward rectifier channels makes the photoresponses more transient (Barnes and Hille, 1989). $\mathrm{IR}_{\mathrm{K}}{ }^{+}$would be expected to alter light responses of horizontal cells similarly. Kaneko and Tachibana (1985) demonstrated that glutamate could inhibit an inward rectifier current in goldfish retinal horizontal cells. Because mGluRs and their intracellularly linked second messenger pathways had not been recognized at the time of their study, these authors did not attempt to identify an mGluR subtype or the intracellular pathways mediating suppression of the inward rectifier. We undertook this present study to elucidate the glutamate receptor type and intracellular signaling pathways mediating this action on $\mathrm{IR}_{\mathrm{K}}{ }^{+}$.

We report that the modulatory signal is transduced via an APB metabotropic glutamate receptor subtype and provide evidence that the intracellular pathway mediating this suppression is a cGMP-dependent second messenger cascade that acts via a protein kinase. From a functional standpoint, it is becoming evident that glutamate can serve two or more postsynaptic roles simultaneously. For example, in horizontal cells, glutamate can be a fast-acting neurotransmitter, and it can be a neuromodulator by regulating 
$\mathrm{IR}_{\mathrm{K}}{ }^{+}$, as demonstrated in this report, and by regulating L-type calcium channels, as reported previously (Dixon et al., 1993).

\section{MATERIALS AND METHODS}

The procedures described below were performed in accordance with the United States Animal Welfare Act and the National Institutes of Health Guide for the Care and Use of Laboratory Animals and were approved by the University of California, San Francisco, Committee on Animal Research.

Preparation of cells. Catfish (Ictalurus punctatus) were dark-adapted for at least $12 \mathrm{hr}$, cooled, swiftly decapitated, and pithed. Enucleated eyes were hemisected, and the retinas were removed. Horizontal cells were isolated using papain digestion and mechanical trituration according to the procedures of Tachibana (1983). Cells were plated onto clean glass coverslips and kept at $14^{\circ} \mathrm{C}$ in a modified (to reduce osmolarity to $\sim 290$ mOsm) L-15 media (GIBCO) for periods ranging from 2 to $20 \mathrm{~d}$. Patch pipette recordings were done at room temperature $\left(20^{\circ} \mathrm{C}\right)$ in a superfusion chamber fitted to the stage of an inverted microscope (IM35; Carl Zeiss). In addition to constant chamber superfusion, the targeted cell was continuously superfused via a Y-tube that allowed rapid, focused solution changes between control salines and those containing drugs or those of modified ionic composition. Continuous, focused superfusion eliminated an artifact that can be caused by local buildup of extracellular potassium (Perlman et al., 1988).

Electrophysiological recordings. Patch pipettes were made on a vertical puller (PP-83; Narishige, Tokyo, Japan) from $1.5 \mathrm{~mm}$ diameter borosilicate glass (Fisher Scientific, Houston, TX). Pipettes had resistances of 2-5 $\mathrm{M} \Omega$ when filled with a solution containing (in $\mathrm{mM}$ ): $\mathrm{K}$ gluconate, 125 ; $\mathrm{NaCl}, 4 ; \mathrm{MgCl}_{2}, 1 ; \mathrm{CaCl}_{2}, 1$; glucose, 10; hemisodium HEPES, 10; EGTA, 2; $\mathrm{Na}_{2} \mathrm{ATP}, 2$; and $\mathrm{NaGTP}, 1$. The $\mathrm{pH}$ was adjusted to 7.4 with $\mathrm{KOH}$. Because our standard intracellular solution has relatively low calcium buffering, we repeated a series of five APB $(20 \mu \mathrm{M})$ experiments with a pipette solution containing $10 \mathrm{~mm}$ EGTA. No differences were noted in the degree of APB-induced $\mathrm{IR}_{\mathrm{K}}{ }^{+}$suppression. The standard superfusion solution contained (in $\mathrm{mM}$ ): $\mathrm{NaCl}, 125 ; \mathrm{KCl}, 5 ; \mathrm{MgCl}_{2}, 1$; $\mathrm{CaCl}_{2}, 2.5$; hemisodium HEPES, 10; and glucose, 16. The $\mathrm{pH}$ was adjusted to 7.8 with $\mathrm{NaOH}$. The $\mathrm{pH}$ and osmolality of all solutions were measured before each experiment. D,L-APB was purchased from both Calbiochem (La Jolla, CA) and Sigma (St. Louis, MO). Glutamate, kainate, 8-Br-cGMP, 8-Br-cAMP, IBMX, GTP $\gamma$ S, and atrial natriuretic peptide (frog) were purchased from Sigma. H-8, H-7, and cholera toxin were purchased from Research Biochemicals (Natick, MA). Adenosine$5 '-O$-[3-thiophosphate] (ATP $\gamma \mathrm{S}$ ) and adenylyl-imidodiphosphate (AMPPNP) were purchased from Boehringer Mannheim (Mannheim, Germany). Rp-8-pCPT-cGMPS was obtained from Biolog (La Jolla, CA). $( \pm)-R S$ - $\alpha$-Methyl-4-carboxyphenylglycine $[( \pm)-\mathrm{MCPG}]$ and trans$(1 S, 3 R)$-1-amino-1,3-cyclopentanedicarboxylic acid [trans- $(1 S, 3 R)$ ACPD] were obtained from Tocris Cookson (Bristol, UK). MCPG was prepared in an $\mathrm{NaOH}$ solution at a concentration of $100 \mathrm{~mm}$. Sodium substitution was mole for mole with lithium, choline, or $N$-methyl-Dglucamine. For solutions containing altered potassium concentrations, the glucose content was altered accordingly. Voltage-clamp recordings were made using an Axopatch 1-A amplifier (Axon Instruments, Foster City, CA) interfaced to a Dell system 200 computer (Austin, TX) through an Indec IDA 15 bit interface (Indec, Sunnyvale, CA) using software developed in the lab by R. Taylor and E. Chen. Inputs were filtered at $2 \mathrm{kHz}$, and the sampling frequency was $0.5 \mathrm{kHz}$ for ramps and $1 \mathrm{kHz}$ for pulses. All voltages have been corrected for junction potentials Cumulative data are expressed as the percent reduction in $\mathrm{IR}_{\mathrm{K}}{ }^{+}$amplitude measured at $-90 \mathrm{mV}$ with variability $( \pm)$ given as the SEM. Recordings were made from cone-driven cells, which are axon bearing in this species (Naka and Carraway, 1975; Dong and Werblin, 1995). The cells selected for recordings had one to three short axon-like extensions emanating from the soma.

\section{RESULTS}

The inward rectifier current is characterized first, and then experiments designed to elucidate the receptor subtype and the intracellular signaling pathways that mediate suppression of this current are presented.

\section{Horizontal cell inward rectifier current}

Current-voltage $(I-V)$ relationships obtained from whole-cell patch-clamp recordings of isolated horizontal cells revealed the inwardly rectifying current. This current is prominent at hyperpolarizing potentials, is markedly reduced by depolarization positive to $-55 \mathrm{mV}$, and is blocked by extracellular barium and cesium but not extracellular tetraethylammonium (TEA) (Fig. 1A) (Tachibana, 1983; Shingai and Christensen, 1986; Dong and Werblin, 1995; Pfeiffer-Linn et al., 1995). Both barium and cesium, in addition to blocking $\mathrm{IR}_{\mathrm{K}}{ }^{+}$at potentials hyperpolarized to $-55 \mathrm{mV}$, cause an inward current shift observed at potentials positive to $-60 \mathrm{mV}$. This inward shift results from the blocking actions by these ions on several electrogenic membrane components; however, part of this shift is likely the result of suppression of an outward component of current through the $\mathrm{IR}_{\mathrm{K}}{ }^{+}$channels, confirming the findings of Dong and Werblin (1995) and indicating that $\mathrm{IR}_{\mathrm{K}}{ }^{+}$contributes some current at resting potentials in darkness for these cells in vivo $(-20$ to $-30 \mathrm{mV})$.

Responses to voltage-clamp pulses, rather than ramps, showed that $\mathrm{IR}_{\mathrm{K}}{ }^{+}$activated rapidly and was essentially noninactivating (Fig. $1 B$ ). A $250 \mathrm{msec}$ portion of the response during the middle of the voltage step (boxed area) was averaged and plotted over the ramp responses $(\Delta)$. The $I-V$ relation determined by the voltage pulse protocol is very similar to the one produced by the less time-consuming voltage ramp protocol. On the basis of this close correspondence, we believed ourselves justified in using the ramp protocol throughout our study.

Activation of this $\mathrm{IR}_{\mathrm{K}}{ }^{+}$, as well as $\mathrm{IR}_{\mathrm{K}}{ }^{+}$in other neurons, is not strictly a function of membrane potential but rather is a combination of membrane potential and the extracellular potassium concentration (Fig. 1C) (Hille, 1992). Because the extracellular potassium concentration in retina is a function of light (Oakley and Steinberg, 1982; Karwoski et al., 1985), we quantified how $\mathrm{IR}_{\mathrm{K}}{ }^{+}$ varied with extracellular potassium. Figure $1 C$ illustrates that with increasing extracellular potassium, the rectification potential shifts positive. [It should be noted here that the term " $\mathrm{IR}_{\mathrm{K}}{ }^{+}$activation" is probably a misnomer, strictly implying a voltage-activated conductance increase. We will use the more precise term " $I R_{\mathrm{K}}{ }^{+}$ rectification potential" to indicate the voltage at which the $I-V$ curve is inflected between the region of lowest and highest conductance (for example, $-55 \mathrm{mV}$ in Fig. 1). The basis for our choice of nomenclature is the common observation that in zero internal $\mathrm{Mg}^{2+}$, the $I-V$ relation is much less rectifying, passing both inward and outward current. These observations demonstrate that the current is activated across the entire voltage range, but the conductance can be influenced by the action of cytosolic components, such as $\mathrm{Mg}^{2+}$ and polyamines (Taglialetla et al., 1995).] Moreover, it is evident that $\mathrm{IR}_{\mathrm{K}}{ }^{+}$channels require some extracellular potassium (Hille, 1992; Lu and MacKinnon, 1994) because in $0 \mathrm{~mm}$ extracellular potassium, there is a complete block of current and an inward shift in current across the entire voltage range. This shift is analogous to that seen in either barium or cesium (see Fig. $1 A$ ), further supporting the notion that this $\mathrm{IR}_{\mathrm{K}}{ }^{+}$passes a limited amount of outward current at potentials positive to the rectification potential. Variations in potassium near in vivo levels (2-3 mM) modified the current at the hyperpolarized potentials, raising the possibility that light-dependent changes in extracellular potassium would modulate $\mathrm{IR}_{\mathrm{K}}{ }^{+}$.

Figure $1 C$ also indicates that $\mathrm{IR}_{\mathrm{K}}{ }^{+}$is permeable to ions other than potassium. For each of the traces shown in this figure, the calculated $E_{\mathrm{K}}{ }^{+}$is $10-20 \mathrm{mV}$ hyperpolarized to the reversal potential of $\mathrm{IR}_{\mathrm{K}}{ }^{+}$. For example, in $5 \mathrm{~mm}\left[\mathrm{~K}^{+}\right]_{\mathrm{o}}$, the predicted $E_{\mathrm{K}}$ is $-82 \mathrm{mV}$, however there is discernible inward current at potentials up to $-60 \mathrm{mV}$.

Figure $1 D$ shows that a portion of $\mathrm{IR}_{\mathrm{K}}{ }^{+}$is in fact carried by 


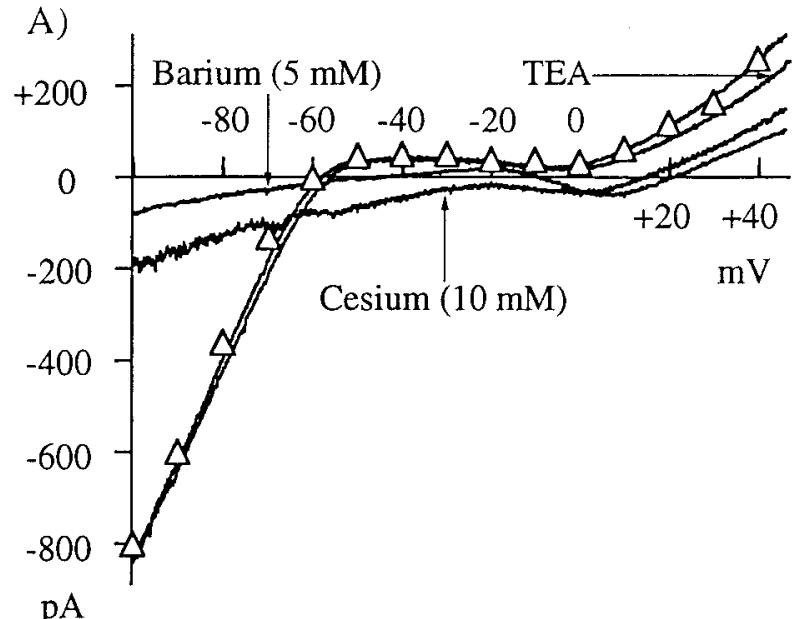

$\mathrm{pA}$

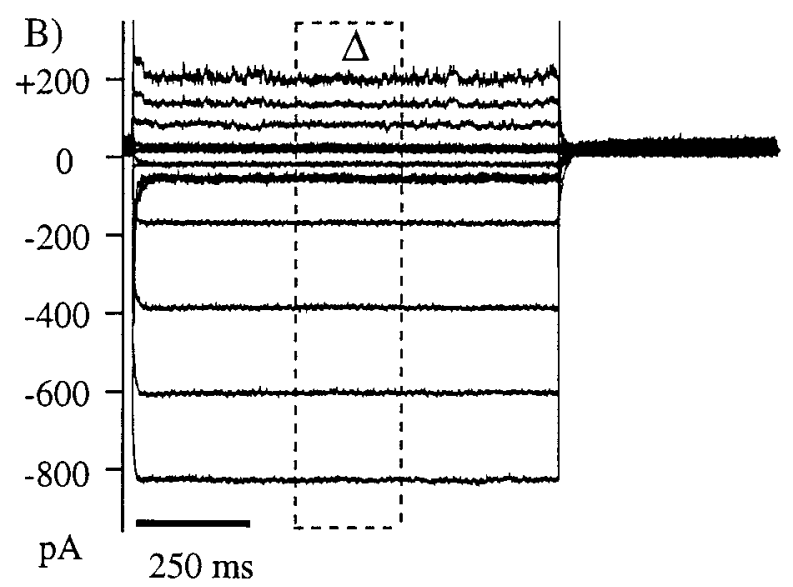

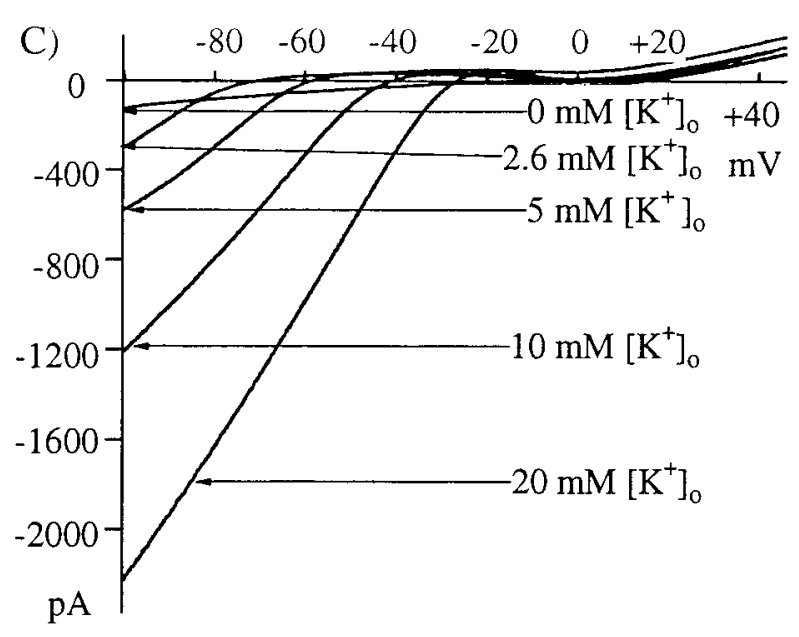

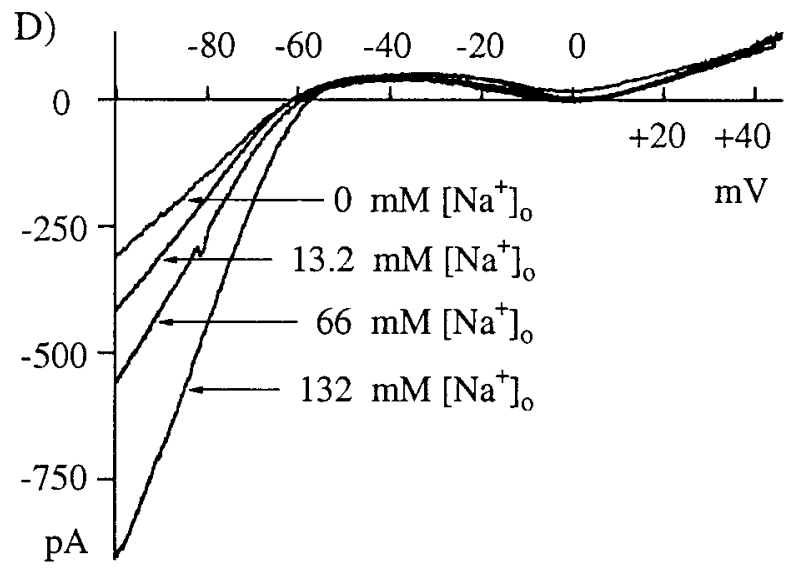

Figure 1. Characterization of the $\mathrm{IR}_{\mathrm{K}}{ }^{+}$in catfish horizontal cells. $A, \mathrm{IR}_{\mathrm{K}}{ }^{+}$is revealed with voltage ramps of the command potential. Cells were held at $-50 \mathrm{mV}$, stepped to $-100 \mathrm{mV}$, and ramped to $+50 \mathrm{mV}$ over a $2 \mathrm{sec}$ period. Ramp durations from 1 to 10 sec produced similar responses. The $I-V$ relation indicates a current that rectifies near $-55 \mathrm{mV}$, reverses from inward to outward near $-60 \mathrm{mV}$, and increases sharply in magnitude with hyperpolarization $(\Delta) \cdot \mathrm{IR}_{\mathrm{K}}{ }^{+}$is blocked by external cesium $(10 \mathrm{mM})$ or barium $(5 \mathrm{~mm})$ but not by TEA $(5 \mathrm{mM})$. Note that TEA does reduce an outward current at membrane potentials positive to $0 \mathrm{mV}$, this being an action on the delayed rectifier potassium current. Moreover, TEA shifts the reversal potential slightly positive, suggesting that TEA may be a permeant ion through this inward rectifier channel. $B$, The cell was held at $-50 \mathrm{mV}$ and then stepped to various potentials $(-100$ to $+50 \mathrm{mV})$ for $1 \mathrm{sec}$. A $250 \mathrm{msec}$ portion of the current response was averaged (boxed area) and plotted along with the ramp responses $(\Delta)$. The current shows a rapid activation and virtually no inactivation. $C, \mathrm{IR}_{\mathrm{K}}{ }^{+}$activation (rectification) is a combined function of membrane potential and extracellular $\mathrm{K}^{+}$. The extracellular $\mathrm{K}^{+}$concentration $\left(\left[\mathrm{K}^{+}\right]_{o}\right)$ was varied from 0 to $20 \mathrm{mM}$. With increasing extracellular $\mathrm{K}^{+}$, current rectification shifts positive. $D$, Sodium permeability of the $\mathrm{IR}_{\mathrm{K}}{ }^{+}$channel is shown. Choline substitution for $\mathrm{Na}^{+}$reduces the current magnitude, shifts the reversal potential slightly, but does not change the rectification potential. In $0 \mathrm{~mm}$ extracellular $\mathrm{Na}^{+}\left(\left[\mathrm{Na}^{+}\right]_{o}\right), \mathrm{IR}_{\mathrm{K}}{ }^{+}$is still inward at potentials positive to $E_{\mathrm{K}}\left(-82 \mathrm{mV}\right.$ in this example), indicating that choline may also permeate this channel, only less so than $\mathrm{Na}^{+}$. All ramps are averages of four successive sweeps.

sodium ions, similar to $\mathrm{IR}_{\mathrm{K}}{ }^{+}$of white bass retinal horizontal cells (Pfeiffer-Linn et al., 1995). In Figure 1D, choline was substituted for sodium; however, similar results were obtained with lithium or $N$-methyl-D-glucamine substitutions. As more and more of the extracellular sodium $\left(\left[\mathrm{Na}^{+}\right]_{\mathrm{o}}\right)$ was replaced, the current magnitude was reduced, and a small change in the rectification potential was evident, which is expected when the extracellular concentration of permeant ions is reduced (Fig. 1C) (Hagiwara and Takahashi, 1974). There is a definite negative shift in $\mathrm{IR}_{\mathrm{K}}{ }^{+}$reversal potential, as expected when the ratio of permeant ions is altered. Still, in the absence of extracellular sodium, there is inwardly rectifying current at potentials positive to the predicted $\mathrm{E}_{\mathrm{K}}$. We confirmed that sodium concentration surrounding the cell was altered as expected by monitoring the TTX-sensitive voltagedependent sodium current in the cells. As $\left[\mathrm{Na}^{+}\right]_{\mathrm{o}}$ was reduced, so too was this current (data not shown). Given that $\left[\mathrm{Na}^{+}\right]_{\mathrm{o}}$ was shown to be reduced, these data suggest that $\mathrm{IR}_{\mathrm{K}}{ }^{+}$is permeable not only to sodium but to the sodium substitutes used here, although to a lesser degree. The shift in reversal potential with changes of extracellular sodium or potassium is consistent with the $\mathrm{IR}_{\mathrm{K}}{ }^{+}$having a $\mathrm{K}^{+} / \mathrm{Na}^{+}$permeability ratio of $\sim 5 / 1$. This value should be interpreted cautiously because it is apparent that the substitutes also have limited permeability.

\section{$\mathrm{IR}_{\mathbf{K}}{ }^{+}$suppression by glutamate and APB}

Glutamate reduced $\mathrm{IR}_{\mathrm{K}}{ }^{+}$in horizontal cells. Figure $2 A$ shows $I-V$ curves measured 2 min before glutamate (Control), $7 \mathrm{~min}$ after glutamate removal (Glutamate), and $10 \mathrm{~min}$ after removal (Recovery). These records demonstrate that the reduction of 

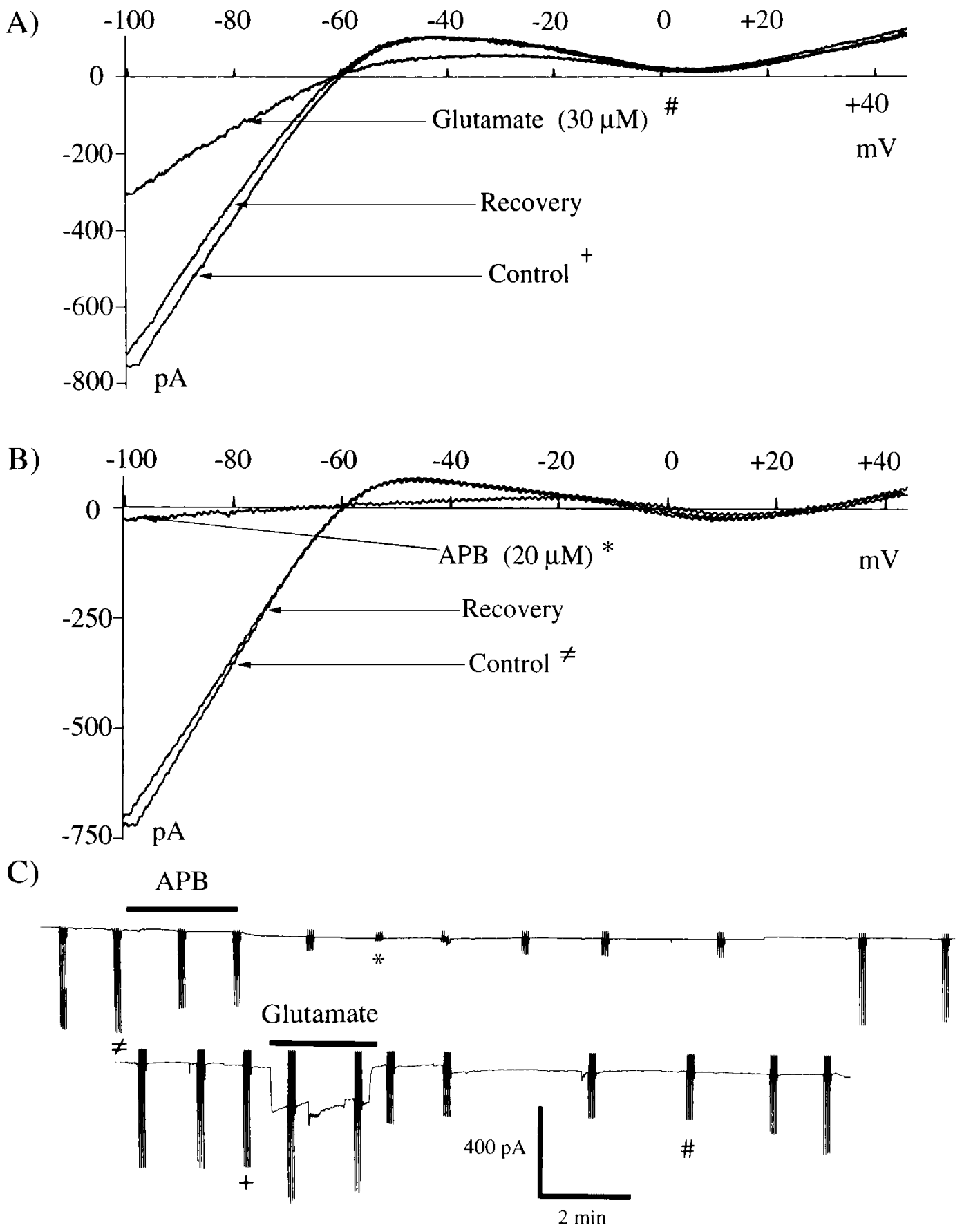

Figure 2. APB and glutamate suppress $\mathrm{IR}_{\mathrm{K}}{ }^{+} . A, 30 \mu \mathrm{M}$ glutamate, applied for $2.3 \mathrm{~min}$, caused an $\sim 55 \%$ suppression of $\mathrm{IR}_{\mathrm{K}}{ }^{+}$as quantified by the reduction of current at $-70 \mathrm{mV}$. The Glutamate trace was recorded $\sim 7 \mathrm{~min}$ after glutamate removal; the Control trace was recorded just before glutamate application. Glutamate-induced suppression of $\mathrm{IR}_{\mathrm{K}}{ }^{+}$persisted well past removal of glutamate, eventually recovering to $95 \%$ of control after 10 min in this example (Recovery). B APB $(20 \mu \mathrm{M})$ for 2.5 min produced a complete suppression of $\mathrm{IR}_{\mathrm{K}}{ }^{+}$. The Control trace was recorded before APB application; the trace labeled $A P B$ was recorded 3 min after APB removal (see $C$ ). $\mathrm{IR}_{\mathrm{K}}{ }^{+}$returned to near control levels after 15 min in this example (Recovery). $C$, Time course of $\mathrm{IR}_{\mathrm{K}}{ }^{+}$suppression is shown. Traces are chart records of the voltage-clamp holding current at $-50 \mathrm{mV}$. In the lower example, $30 \mu \mathrm{M}$ glutamate (solid bar above the trace) produced an $\sim 60 \%$ suppression of $\mathrm{IR}_{\mathrm{K}}{ }^{+}$that recovered after 10 min. Sample expanded ramp responses $(\#,+)$ are shown in $A$. The increased amplitude of the ramp responses during glutamate addition reflects the increased input conductance resulting from ionotropic glutamate receptors. To construct the $I-V$ curves in $A$, we subtracted the ionotropic component of the current. In the top trace, the cell was exposed to $20 \mu \mathrm{M}$ APB (2.5 min) as indicated by the solid bar above the trace. During and for a period of time after APB addition, the ramp response magnitude was decreased, indicated by the reduction in amplitude of the vertical response lines.

$\mathrm{IR}_{\mathrm{K}}{ }^{+}$by glutamate outlasted the application of glutamate but was completely reversed $\sim 10$ min after glutamate removal.

APB also suppressed $\mathrm{IR}_{\mathrm{K}}{ }^{+}(n=16$ of 16 cells tested). Figure $2 B$ shows one cell in which $I-V$ curves were obtained 2 min before
APB (Control), 3 min after removal $(A P B)$, and 15 min after removal (Recovery). In this cell the suppressive effect of APB was more pronounced than was that of glutamate in Figure $2 A$, but it still was reversed 15 min after APB removal. 
Glutamate produced both a fast-acting inward current in these cells, via activation of the ionotropic glutamate receptors, and a slower modulatory action on $\mathrm{IR}_{\mathrm{K}}{ }^{+}$. Figure $2 C$ shows that both the onset and termination of the suppression of $\mathrm{IR}_{\mathrm{K}}{ }^{+}$was much slower than was that of the ionotropic current. These tracings are continuous recordings of the horizontal cell responses during the application and removal of glutamate and APB. The large vertical deflections are the voltage ramp responses (groups of four for averaging). Their total displacements reflect $\mathrm{IR}_{\mathrm{K}}{ }^{+}$magnitude. In the bottom trace, $30 \mu \mathrm{M}$ glutamate produces not only a large ionotropic inward current but suppresses $\mathrm{IR}_{\mathrm{K}}{ }^{+}$for $\sim 10 \mathrm{~min}$. The increased magnitude of ramp responses during glutamate does not represent an increase in $\mathrm{IR}_{\mathrm{K}}{ }^{+}$amplitude; rather it is because of the increased membrane conductance caused by the opening of ionotropic glutamate channels. The marked responses $(+, \#)$ are shown in Figure $2 A$. Both the fast-acting excitatory and slower modulatory actions of glutamate were observed in 14 of 14 cells. In the top trace of Figure $2 C, 20 \mu \mathrm{M}$ APB produces a complete $\mathrm{IR}_{\mathrm{K}}{ }^{+}$suppression (note shortened ramp responses) that recovers after $\sim 15 \mathrm{~min}$. The designated $I-V$ responses $(*, \neq)$ are shown on an expanded scale in Figure $2 B$. An important conclusion derived from the APB recordings is that an ionic flux via glutamate ionotropic channels is not a prerequisite for $\mathrm{IR}_{\mathrm{K}}{ }^{+}$suppression because APB, which produces no ionic current, fully blocks $\mathrm{IR}_{\mathrm{K}}{ }^{+}$. This indicates that influx of calcium or sodium is not required for stimulation of the pathways leading to suppression of $\mathrm{IR}_{\mathrm{K}}{ }^{+}$. Instead, the slowness of the action on $\mathrm{IR}_{\mathrm{K}}{ }^{+}$hints that glutamate and APB may trigger an intracellular second messenger pathway within the cells.

Although cell-to-cell variations were evident, the degree and duration of $\mathrm{IR}_{\mathrm{K}}{ }^{+}$suppression increased with agonist concentration and exposure duration. For our relatively brief agonist applications (2-2.5 min), we found APB to be effective at concentrations as low as $5 \mu \mathrm{M}$ and found its effects to be maximal and often irreversible at $25 \mu \mathrm{M}$ (at $20 \mu \mathrm{M}, 86.3 \pm 12.8 \%$ [mean percent suppression $\pm \mathrm{SEM}$; $n=6)$. Glutamate was a little less potent with observable effects at $10 \mu \mathrm{M}$ and maximal effects at $50 \mu \mathrm{M}$ (at $30 \mu \mathrm{M}, 61.3 \pm 22.4 \% ; n=6)$. We found that agonist exposures in excess of 10 min often resulted in irreversible $\mathrm{IR}_{\mathrm{K}}{ }^{+}$suppression. Given this finding, it is credible that longer applications of APB or glutamate would have produced effects at concentrations much lower than we used here.

Neither kainate (up to $50 \mu \mathrm{M}$ ), an agonist for non-NMDA glutamate receptors, nor trans-( $1 S, 3 R$ )-ACPD (up to $100 \mu \mathrm{M}$ ), an agonist at several non-APB-sensitive metabotropic receptors, caused any suppression of $\mathrm{IR}_{\mathrm{K}}{ }^{+}$(Fig. 3A). The metabotropic receptor antagonist (see Jane et al., 1995) MCPG (1 mM) was unable to block the effect of $\mathrm{APB}$ on $\mathrm{IR}_{\mathrm{K}}{ }^{+}$. In Figure $3 B$ the effects of APB were studied in the presence of MCPG. There is no discernible efficacy of MCPG on the suppression of $\mathrm{IR}_{\mathrm{K}}{ }^{+}$by APB $(20 \mu \mathrm{M})$. Similar results were obtained in four of four cells tested with MCPG at concentrations up to $1 \mathrm{mM}$. These results support the hypothesis that glutamate and APB are most likely activating an APB-sensitive metabotropic receptor and that activation of an ionotropic glutamate receptor is not required for suppression of $\mathrm{IR}_{\mathrm{K}}{ }^{+}$.

\section{Action of cyclic nucleotides on $\mathbf{I R}_{\mathbf{K}}{ }^{+}$}

$\mathrm{IR}_{\mathrm{K}}{ }^{+}$could be suppressed both by a cGMP analog and by the phosphodiesterase inhibitor 1-methyl-3-isobutylxanthine (IBMX) but not by a cAMP analog. Figure $4 A$ shows an example in which the phosphodiesterase-resistant cGMP analog 8-Br-cGMP was
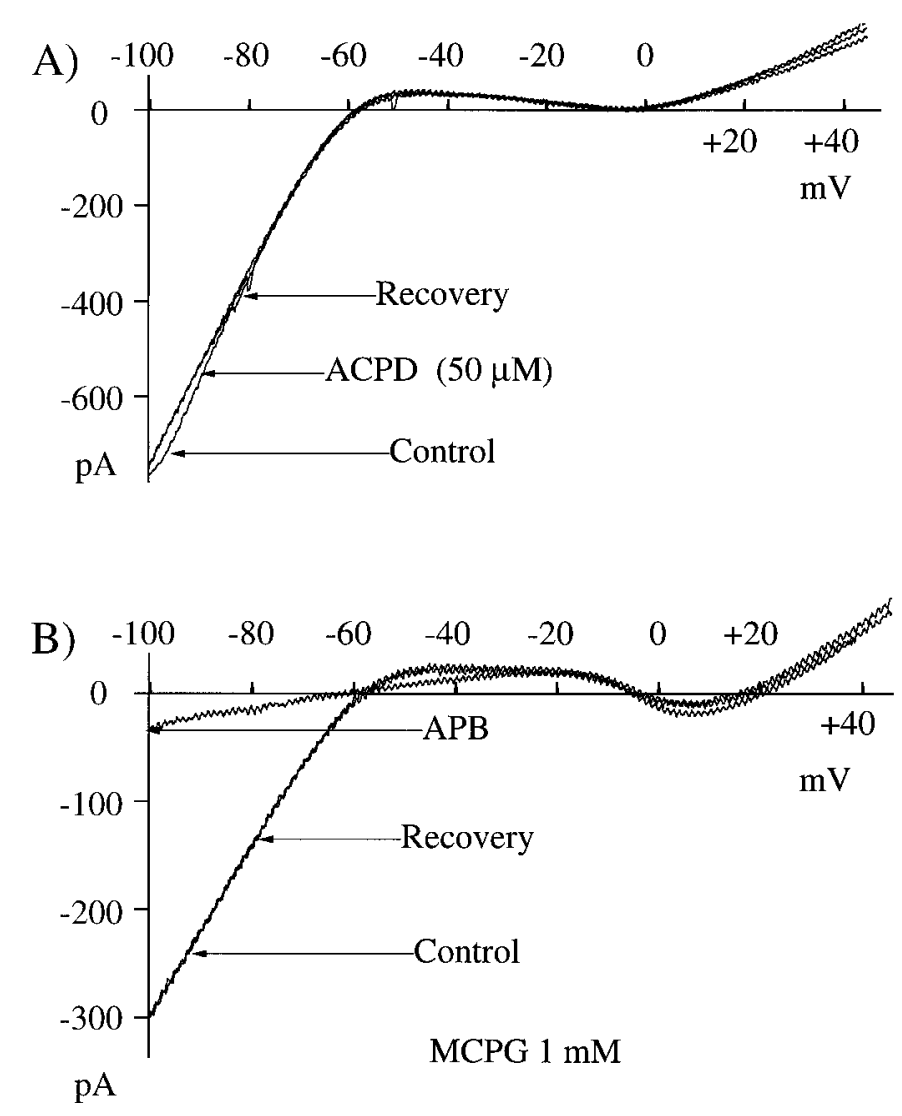

Figure 3. ACPD does not suppress $\mathrm{IR}_{\mathrm{K}}{ }^{+}$, nor does MCPG block the action of APB on $\mathrm{IR}_{\mathrm{K}}{ }^{+} \cdot A, 50 \mu \mathrm{M}$ ACPD was applied to the cell for $2 \mathrm{~min}$. The Control trace was recorded before ACPD application, ACPD was recorded at the end of the 2 min application, and Recovery was recorded 12 min after ACPD removal. $B$, After recording of the control $I-V$ (Control), the cell was bathed in MCPG for $3 \mathrm{~min}$. APB was applied for 2 min starting $30 \mathrm{sec}$ after MCPG. APB and Recovery were recorded just before and $10 \mathrm{~min}$ after APB removal. In this figure it is demonstrated that MCPG did not inhibit the actions of APB.

included in the patch pipette at a concentration of $1 \mathrm{~mm}$. 8-BrcGMP almost completely blocked $\mathrm{IR}_{\mathrm{K}}{ }^{+}(97.3 \pm 18.1 \% ; n=5)$. In this figure, the control trace was recorded within $30 \mathrm{sec}$ of breaking into the cell. Within 5 min of breaking into the cell, $\mathrm{IR}_{\mathrm{K}}{ }^{+}$was no longer evident (Fig. 4A,D). In some experiments, subsequent addition of barium $(1 \mathrm{~mm})$ or cesium $(10 \mathrm{~mm})$ failed to reduce $\mathrm{IR}_{\mathrm{K}}{ }^{+}$ further, confirming that this analog had completely suppressed $\mathrm{IR}_{\mathrm{K}}{ }^{+}$. By contrast, Figure $4 B$ shows that 8 -Br-cAMP (1 mM) had no discernible effect on $\mathrm{IR}_{\mathrm{K}}{ }^{+}$even after $25 \mathrm{~min}(3.1 \pm 8.4 \% ; n=$ 8). A comparison of the full time course for the effects of pipetteapplied cGMP (open symbols) and cAMP (filled symbols) is presented in Figure $4 D$. As a positive control, we found that 8-BrcAMP did progressively reduce the L-type calcium current in these cells, as noted by the change in current positive to $-20 \mathrm{mV}$ (Fig. 4B). cAMP-mediated reduction of the L-type current in these and other retinal cells has been demonstrated previously (Liu and Lasater, 1994) (B. N. Christensen and F. Zanebi, personal communication). Extracellular application of 8-Br-cAMP and 8Br-cGMP produced results similar to that seen with internal perfusion; however, the extent of $\mathrm{IR}_{\mathrm{K}}{ }^{+}$suppression by 8-Br-cGMP was generally less and progressed more slowly. When IBMX was included in the patch pipette solution (Fig. $4 C$ ), the magnitude of $\mathrm{IR}_{\mathrm{K}}{ }^{+}$slowly decreased $(19.8 \pm 7.8 \% ; n=5)$. In this example the 

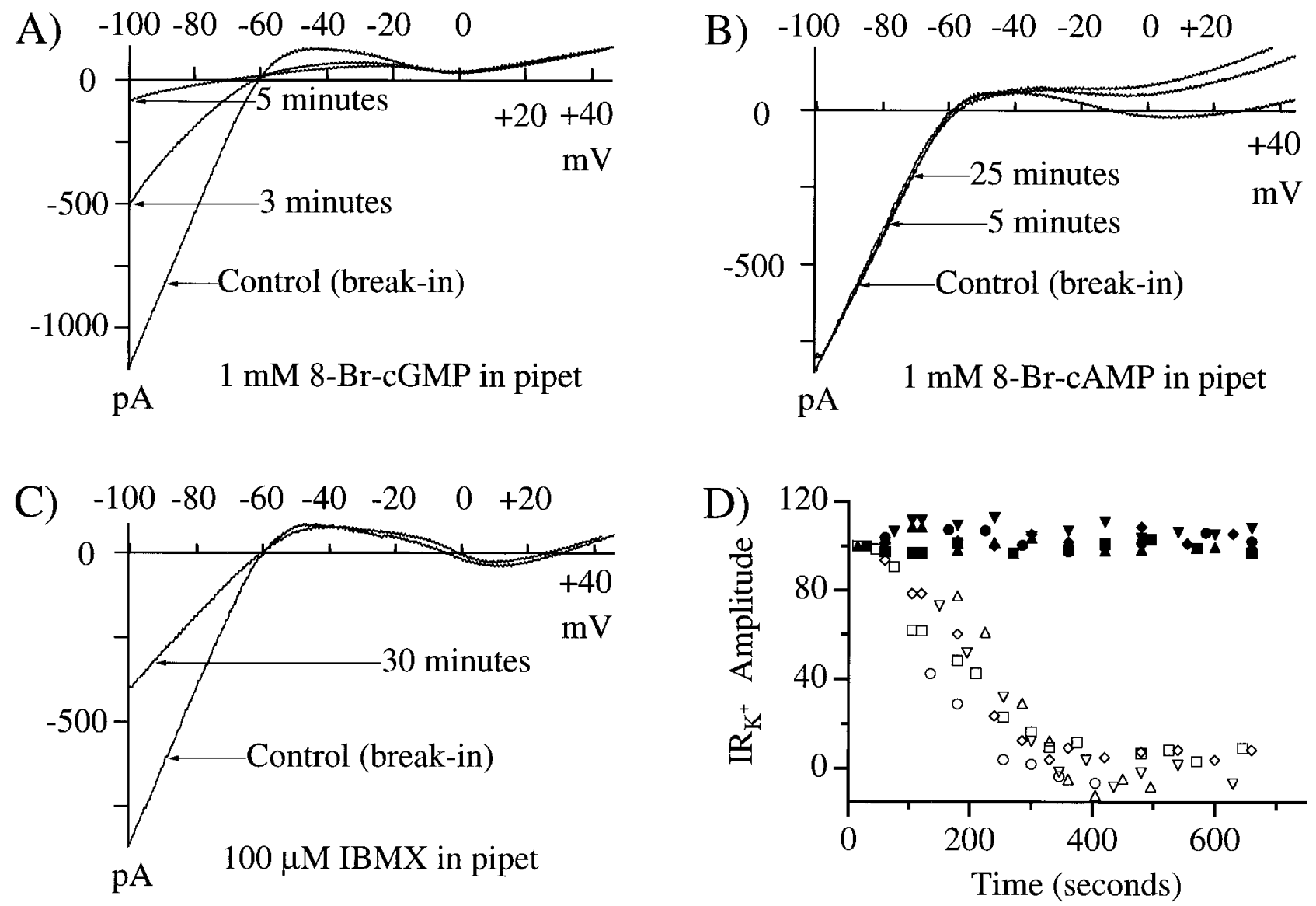

Figure 4. 8-Br-cGMP but not 8-Br-cAMP reduces $\mathrm{IR}_{\mathrm{K}}{ }^{+} \cdot A, 8$-Br-cGMP mimicked the action of APB or glutamate by suppressing IR ${ }_{\mathrm{K}}^{+}$. 8-Br-cGMP $(1 \mathrm{mM})$ in the pipette eliminated $\mathrm{IR}_{\mathrm{K}}{ }^{+}$within 5 min of membrane rupture. $B, 8$-Br-cAMP $(1 \mathrm{mM})$ failed to affect $\mathrm{IR}_{\mathrm{K}}{ }^{+}$but did influence the calcium current. In this example, even after $25 \mathrm{~min}, \mathrm{IR}_{\mathrm{K}}{ }^{+}$is unchanged, whereas the calcium current is effectively eliminated. $C, \mathrm{IBMX}(100 \mu \mathrm{M})$ included in the patch pipette led to a slow, progressive suppression of $\mathrm{IR}_{\mathrm{K}}{ }^{+}$. In all of these experiments, the response labeled Control was recorded within 30 sec of membrane rupture; the experimental traces were recorded as indicated on the figure. All traces are averages of four successive ramps. $D$, Time course for the effects of cyclic nucleotides is shown. Each symbol represents one experiment; open symbols are for 8-Br-cGMP $(n=5)$, and filled symbols are for 8-Br-cAMP $(n=5)$. Current amplitude represents the percent of control (time, $30 \mathrm{sec}$ ) measured at $-90 \mathrm{mV}$ for the various time points. Complete $\mathrm{IR}_{\mathrm{K}}{ }^{+}$suppression was determined by subsequent application of $1 \mathrm{~mm} \mathrm{Ba}^{2+}$. Some values exceed $100 \%$ limits because the $\mathrm{Ba}^{2+}$ treatment often shifted the entire $I-V$ relation slightly more negative (see Fig. 1).

control trace was recorded within $30 \mathrm{sec}$ of breaking into the cell. The test trace was recorded 30 min later. This rather small effect, combined with the slow onset, is consistent with the idea that the basal guanylyl cyclase activity is low in these cells. These data demonstrate that $\mathrm{IR}_{\mathrm{K}}{ }^{+}$suppression can be produced by an increase in intracellular cGMP concentration but is not affected by increases in cAMP.

In ON bipolar cells, activation of the APB-sensitive mGluR6 receptor is thought to decrease intracellular cGMP, thereby closing cGMP-activated cationic channels in the plasma membrane of the cells (Nawy and Jahr, 1990). In the ON bipolar cells, intracellular perfusion of cGMP or 8 -Br-cGMP activates the cyclic nucleotide channels to produce a sustained inward current. In these present experiments, neither cGMP analogs nor IBMX elicited an inward current independent of the suppression of $\mathrm{IR}_{\mathrm{K}}{ }^{+}$. Hence the actions of APB, glutamate, and cGMP are fundamentally different in horizontal versus ON bipolar cells.

To identify the possible second messenger cGMP-mediated intracellular pathways by which APB might be linked to $\mathrm{IR}_{\mathrm{K}}{ }^{+}$ suppression, we examined the actions of glutamate and APB in the presence of the selective cGMP-dependent protein kinase inhibitor Rp-8-pCPT-cGMPS or the more broad spectrum kinase inhib- itors $\mathrm{H}-8$ or H-7. When the patch pipette solution contained Rp8-pCPT-cGMPS $(2.5 \mu \mathrm{M})$, neither glutamate $(6.1 \pm 11.2 \%$; $n=5$; Fig. $5 A)$ nor APB $(10.9 \pm 16.4 \% ; n=5$; data not shown), at near maximal concentrations, significantly suppressed $\mathrm{IR}_{\mathrm{K}}{ }^{+}$. The concentration of Rp-8-pCPT-cGMPS used here is five times greater than the reported $K_{\mathrm{i}}$ for cGMP-dependent protein kinase yet three times below that reported for cAMP-dependent protein kinase (Butt et al., 1994), providing strong evidence that the glutamatergic $\mathrm{IR}_{\mathrm{K}}{ }^{+}$suppression pathway depends on a kinase that is cGMP dependent. Figure $5 B$ is an example of $\mathrm{H}-8$ blocking the suppression of $\mathrm{IR}_{\mathrm{K}}{ }^{+}$by APB. These records show that $\mathrm{IR}_{\mathrm{K}}{ }^{+}$remained unchanged by APB. H-7 acted similarly (data not shown). In H-8 or $\mathrm{H}-7, \mathrm{IR}_{\mathrm{K}}{ }^{+}$could not be suppressed even with longer or repeated applications of glutamate or APB (data not shown). Because H-7 and $\mathrm{H}-8$ are less selective protein kinase inhibitors, these data cannot be used to distinguish between a cGMP or cAMP kinase, but they do provide strong confirmatory evidence that a kinase links APB receptors to suppression of $\mathrm{IR}_{\mathrm{K}}{ }^{+}$.

We tested whether an ATP-dependent step might link or regulate APB receptor activation to suppression of $\mathrm{IR}_{\mathrm{K}}{ }^{+}$. We used $\mathrm{ATP} \gamma \mathrm{S}$, which can be a substrate for some protein kinases but is a poor one for ATPases (Eckstein, 1985), and AMP-PNP, which 

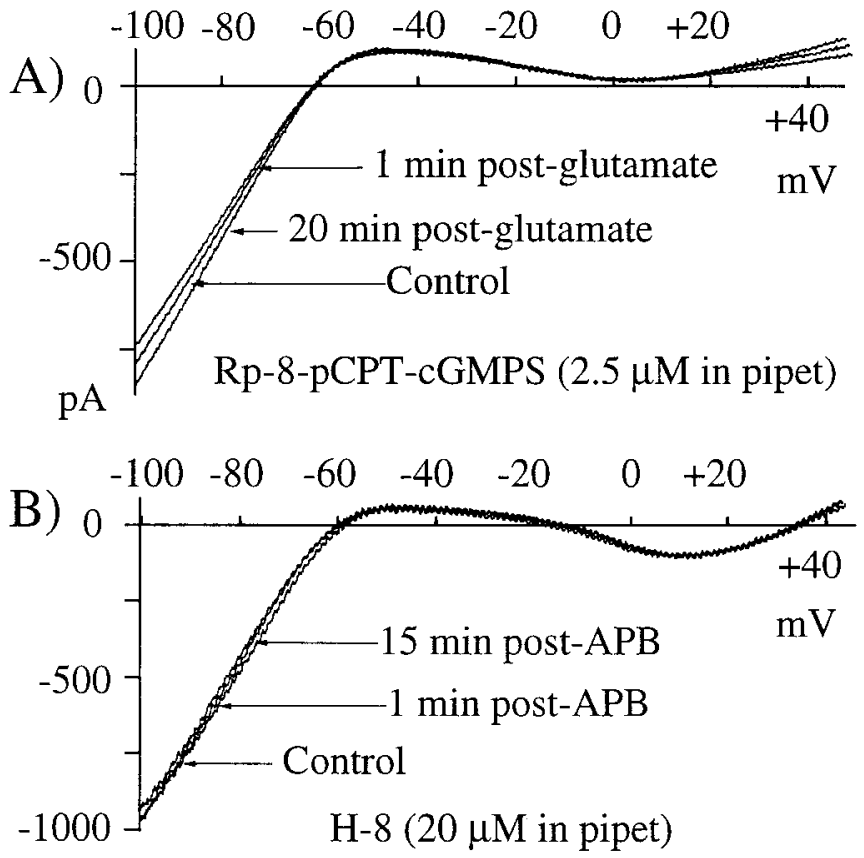

$\mathrm{pA}$

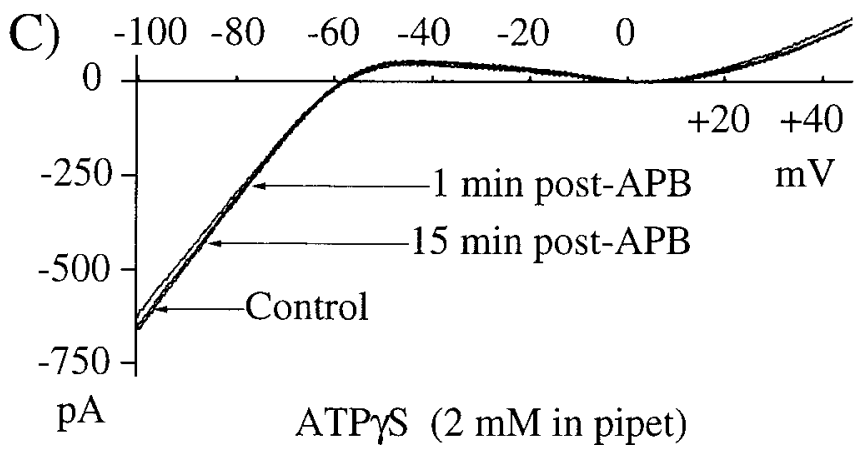

Figure 5. Kinase inhibitors and ATP analogs block the action of APB and glutamate. $A$, Glutamate suppression of $\mathrm{IR}_{\mathrm{K}}{ }^{+}$was blocked when the patch pipette contained the kinase inhibitor Rp-8-pPCT-cGMPS (2.5 $\mu \mathrm{M})$. In this example, a maximal dose of glutamate $(50 \mu \mathrm{M})$ failed to affect $\mathrm{IR}_{\mathrm{K}}{ }^{+}$. The trace labeled glutamate was recorded 2 min after glutamate removal. Glutamate produced a normal ionotropic current but failed to reduce $\mathrm{IR}_{\mathrm{K}}{ }^{+}$magnitude during or after glutamate application. $B$, The kinase inhibitor $\mathrm{H}-8$ was included in the patch pipette at a concentration of $20 \mu \mathrm{M}$. The $I-V$ curves taken before (Control) and at 1 and 15 min after APB $(20 \mu \mathrm{M})$ superimposed, indicating that $\mathrm{H}-8$ uncoupled receptor activation from suppression of $\mathrm{IR}_{\mathrm{K}}{ }^{+}$. $C$, ATP $\gamma \mathrm{S}(2 \mathrm{~mm})$ administered via the patch pipette blocks the action of APB on $\mathrm{IR}_{\mathrm{K}}{ }^{+}$. In this example, 20 $\mu \mathrm{M}$ APB causes little if any reduction in $\mathrm{IR}_{\mathrm{K}}{ }^{+}$(compare with Fig. 2B,C). Ramps were recorded as described in Figure $2 B$. All traces are averages of four ramps.

is an hydrolysis resistant ATP analog. When cells were dialyzed with $2 \mathrm{~mm} \mathrm{ATP} \gamma \mathrm{S}(0.1 \mathrm{~mm}$ ATP and $1 \mathrm{~mm}$ GTP $)$, the action of APB on $\mathrm{IR}_{\mathrm{K}}{ }^{+}$was eliminated (Fig. $5 C$ ). In the example shown, the control trace was acquired before a $2.5 \mathrm{~min} 20 \mu \mathrm{M}$ APB exposure; the test trace was recorded 2 min after APB removal. At best there is a small reduction of $\mathrm{IR}_{\mathrm{K}}{ }^{+}$, much less than is typically seen with this concentration of APB (see Fig. $2 B$ ). In a total of eight trials using ATP $\gamma \mathrm{S}$ (APB, $n=5$; glutamate, $n=3$ ), $\mathrm{IR}_{\mathrm{K}}{ }^{+}$ magnitude was reduced $5.1 \pm 11.5 \%$. AMP-PNP (1-5 mM and 0.1 mM ATP) was less potent than ATP $\gamma \mathrm{S}$ and more variable, but it still reduced the effectiveness of either glutamate or APB at
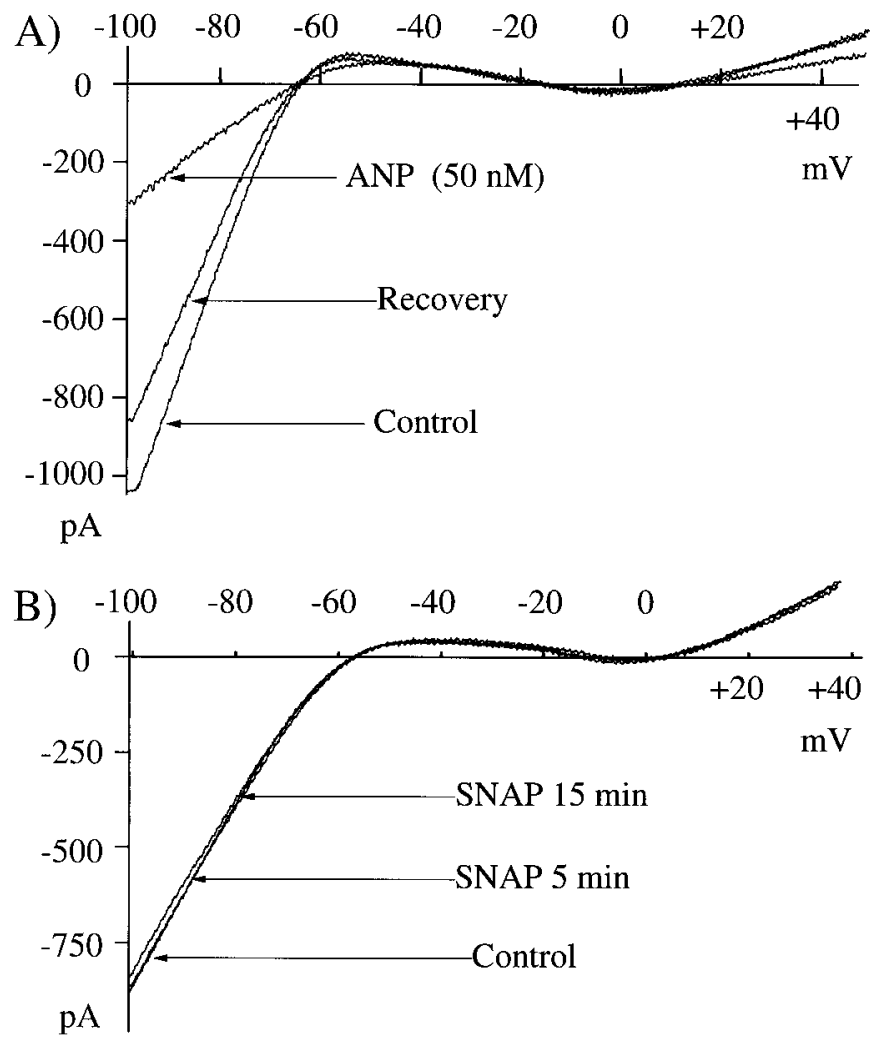

Figure 6. ANP suppressed $\mathrm{IR}_{\mathrm{K}}{ }^{+}$, but SNAP had no effect. $A$, A 5 min application of ANP (50 nM) produced an $\sim 70 \%$ suppression of $\mathrm{IR}_{\mathrm{K}}{ }^{+}$that recovered 22 min after removal. The trace labeled $A N P$ was recorded 2 min after removal of ANP. B, Freshly mixed SNAP was perfused at a concentration of $1 \mathrm{~mm}$. No effect on $\mathrm{IR}_{\mathrm{K}}{ }^{+}$was observed. In both examples, the control trace was recorded before agonist application, and the test traces were recorded after agonist removal. All traces are averages of four successive ramps.

suppressing $\mathrm{IR}_{\mathrm{K}}{ }^{+}$. The degree of $\mathrm{IR}_{\mathrm{K}}{ }^{+}$suppression (11.8 \pm $15.3 \% ; n=9$ ) was always less than that seen at the same agonist concentration in the absence of AMP-PNP. Taken together, these findings provide evidence that an ATP-dependent phosphorylation step plays a role in linking activation of the APB receptor to suppression of $\mathrm{IR}_{\mathrm{K}}{ }^{+}$.

Experiments with atrial natriuretic peptide (ANP) indicated that an independently activated cGMP cascade could suppress $\mathrm{IR}_{\mathrm{K}}{ }^{+}$. ANP, a hormone involved in regulation of diuresis, blood pressure, and water balance, has been localized in the retinas of several species (Palm et al., 1989). The receptor of this peptide exerts its actions via stimulation of a guanylyl cyclase that is an integral part of the receptor moiety (Chinkers et al., 1989; Duda et al., 1993). We found that ANP suppresses $\operatorname{IR}_{\mathrm{K}}{ }^{+}(n=10)$ in isolated horizontal cells (Fig. 6A). The effect is reversible and requires $3-5 \mathrm{~min}$ to develop. In this example (Fig. 6A), the Control trace was recorded before a 5 min superfusion with $50 \mathrm{nM}$ ANP. The ANP trace was recorded 2 min after removal of ANP, and the Recovery trace was recorded 22 min after ANP removal. $\mathrm{IR}_{\mathrm{K}}{ }^{+}$suppression was maximal $(\sim 70 \%)$ after $5 \min$ in $50 \mathrm{~nm}$ ANP, recovering slowly over the next $20-25$ min. ANP was effective at concentrations from 5 to $50 \mathrm{~nm}(n=10)$, resulting in $\sim 25-70 \%$ suppression. Given the specificity of the activation of guanylyl cyclase by ANP, these data independently provide evidence of the existence of a cGMP-mediated intracellular mechanism that can modulate $\mathrm{IR}_{\mathrm{K}}{ }^{+}$. Nitric oxide (NO) can stimulate 
soluble forms of guanylyl cyclase to generate cGMP (Ahmad et al., 1994). Our efforts to suppress $\mathrm{IR}_{\mathrm{K}}{ }^{+}$via a nitric oxidemediated change in cGMP failed. Cells were incubated for up to $10 \mathrm{~min}$ in the NO donor $S$-nitroso- $N$-acetylpenicillamine (SNAP; $1 \mathrm{~mm})$. No reduction in $\mathrm{IR}_{\mathrm{K}}{ }^{+}$was observed anytime during incubation or during periods up to $1 \mathrm{hr}$ after incubation. Identical concentrations of SNAP were found to modify light responses of ganglion cells in tiger salamander retina $(\mathrm{N}$. Tian and D. R. Copenhagen, unpublished observations). Figure $6 B$ shows an $I-V$ curve recorded from a cell before, during, and after the application of SNAP. NO production from SNAP was verified using an amperometric nitric oxide detector (Inter Medic Corporation). Because NO targets the soluble form of guanylyl cyclase (Katsuki et al., 1977), these data would suggest that APB, analogous to ANP, activates a membrane form of a guanylyl cyclase; however, intracellular dialysis via the patch pipette may have diluted an existing soluble form of the guanylyl cyclase to inconsequential levels. Thus, this conclusion must remain tentative.

The action of APB and glutamate on $\mathrm{IR}_{\mathrm{K}}{ }^{+}$was blocked by adding GTP $\gamma$ S, a hydrolysis-resistant GTP analog, to the patch pipette or by preincubating the cells in cholera toxin (data not shown). These findings suggest that a GTP binding protein is likely to regulate the APB signaling pathway in these cells. Further work will be needed to establish the site or sites at which cholera toxin and GTP $\gamma \mathrm{S}$ act in this pathway.

\section{DISCUSSION}

\section{Horizontal cell $\mathbf{I R}_{\mathbf{K}}{ }^{+}$}

Electrophysiological (Hille, 1992) and molecular studies (Doupnik et al., 1995) indicate that $\mathrm{IR}_{\mathrm{K}}{ }^{+} \mathrm{S}$ are a family of channels. Certain key features that are conserved include a $\mathrm{K}^{+}$dependent rectification potential (Fig. $1 C$ ) and a block by cesium (Fig. $1 A$ ). Based on the block of catfish horizontal cell $\mathrm{IR}_{\mathrm{K}}{ }^{+}$by low concentrations of barium and a limited permeability to sodium, it most closely resembles the starfish $\mathrm{IR}_{\mathrm{K}}{ }^{+}$reported by Hagiwara and Takahashi (1974); however, catfish $\mathrm{IR}_{\mathrm{K}}{ }^{+}$shows reduced ionic selectivity (Fig. 1D; Takahashi and Copenhagen, 1995 ) and faster activation kinetics (Fig. 1B). Catfish $\mathrm{IR}_{\mathrm{K}}{ }^{+}$ strongly resembles $\mathrm{IR}_{\mathrm{K}}{ }^{+}$recorded from horizontal cells of white bass retina that also show some sodium permeability (PfeifferLinn et al., 1995).

\section{Glutamate modulation of $\mathbf{I R}_{\mathbf{K}}{ }^{+}$}

Glutamate, the endogenous neurotransmitter released from photoreceptors (Copenhagen and Jahr, 1989), activates ionotropic receptors on the catfish retinal horizontal cells (O'Dell and Christensen, 1989). Our data indicate that glutamate also activates an APB-sensitive metabotropic receptor that suppresses $\mathrm{IR}_{\mathrm{K}}{ }^{+}$(Fig. 2). The onset of $\mathrm{IR}_{\mathrm{K}}{ }^{+}$suppression occurs in 1-3 min and outlasts the duration of glutamate application, and its consequent activation of ionotropic receptor-gated currents, by up to 20 min (Fig. 2). The time course of suppression is consistent with a second messenger cascade (Fig. 2C; see also Fig. 6). $\mathrm{IR}_{\mathrm{K}}{ }^{+}$suppression is mimicked by IBMX and cGMP analogs but not by cAMP analogs (Fig. 4). APB-, glutamate-, and 8-Br-cGMPmediated $\mathrm{IR}_{\mathrm{K}}{ }^{+}$suppression is eliminated when cells are dialyzed with broad spectrum kinase inhibitors such as H-8 and H-7 (data not shown). Furthermore, Rp-8-pCPT-cGMPS, used here at a concentration that is specific for cGMP-dependent kinase (Butt et al., 1994), eliminates glutamate- (Fig. 5A) and APB-evoked $\mathrm{IR}_{\mathrm{K}}{ }^{+}$suppression. ANP, a hormone that operates exclusively via guanylyl cyclase (Chinkers et al., 1989; Duda et al., 1993), also suppresses $\mathrm{IR}_{\mathrm{K}}{ }^{+}$in these horizontal cells (Fig. 6A). APB-evoked suppression of $\mathrm{IR}_{\mathrm{K}}{ }^{+}$was blocked by intracellular perfusion of ATP $\gamma \mathrm{S}$ and was curtailed by AMP-PNP.

\section{Proposed model for APB receptor-mediated suppression of $\mathbf{I R}_{\mathbf{K}}{ }^{+}$}

The actions of ANP and 8-Br-cGMP provide evidence of the hypothesis that cGMP mediates the modulation of $\mathrm{IR}_{\mathrm{K}}{ }^{+}$. Precedent shows that cGMP can exert its action by binding to three different classes of protein; it can bind and activate plasma membrane-bound cyclic nucleotide-gated channels, cAMPdependent phosphodiesterases (PDE), and cGMP-selective protein kinases (Goy, 1991; Shabb and Corbin, 1992). Here we showed that 8-Br-cGMP did not generate a current in the horizontal cells, although other studies have shown that cGMP-gated channels are found not only in $\mathrm{ON}$ bipolar cells but in ganglion cells (Ahmad et al., 1994) and cone photoreceptors (Rieke and Schwartz, 1994). Also, 8-Br-cAMP had no effect on $\mathrm{IR}_{\mathrm{K}}{ }^{+}$, so it is unlikely that cGMP is indirectly regulating cAMP to suppress $\mathrm{IR}_{\mathrm{K}}{ }^{+}$. For these reasons, it seems most reasonable to assume that cGMP is not exerting its effects by binding an ion channel or by regulating the activity of a cAMP-dependent PDE. Instead it seems most plausible that cGMP is acting via an endogenous cGMP-dependent protein kinase (Fig. 7). This hypothesis is supported by the findings that $\mathrm{H}-7, \mathrm{H}-8$, and particularly Rp-8pCP-cGMPS blocked the suppressive action of APB and glutamate on $\mathrm{IR}_{\mathrm{K}}{ }^{+}$.

The model requires that activation of the APB receptor increases intracellular cGMP. The technical difficulty in measuring cyclic nucleotide concentration changes in single cells prevents us from directly measuring this putative increase in these cells. In our model, theoretically, cGMP concentration could be elevated by either inhibition of a phosphodiesterase or stimulation of a guanylyl cyclase. We postulate that cGMP is increased by the latter mechanism because IBMX was relatively weak in suppressing $\mathrm{IR}_{\mathrm{K}}{ }^{+}$and ANP receptors are known to directly stimulate guanylyl cyclase activity. If indeed activation of guanylyl cyclase is stimulated by a metabotropic glutamate receptor, this would be a novel signaling pathway (Nakanishi, 1992; Bockaert et al., 1993).

Further experiments will be required to establish at what sites ATP $\gamma \mathrm{S}$ was acting. It could have been acting as a substrate for a kinase that phosphorylated the inward rectifier channel directly or a phosphatase that acted on the channel (White et al., 1995). Alternatively, these data do not eliminate an action of ATP $\gamma \mathrm{S}$ on a kinase that regulates the metabotropic receptor itself. Nonetheless, these findings do implicate a kinase-mediated phosphorylation step in the direct pathway linking mGluR to $\mathrm{IR}_{\mathrm{K}}{ }^{+}$or in the regulation of this pathway.

\section{Candidates for the mGluR subtype on horizontal cells}

In ON bipolar cells, glutamate binds an mGluR6-type receptor (Nakanishi, 1992). This receptor is localized to the ON bipolar dendrites and is not found in horizontal cells. In situ hybridization shows mGluR5 mRNA in rat horizontal cells (Hartveit et al., 1995). mGluR5 is generally classified as a group I metabotropic receptor in that it is more selective for quisqualate than for APB and stimulates phospholipase C (Pin and Duvoisin, 1995). Based on agonist selectivity, APB-evoked suppression of $\mathrm{IR}_{\mathrm{K}}{ }^{+}$would probably not be mediated via an mGluR5 receptor. Two studies show weak expression of the APB-sensitive mGluR7 receptors in rat horizontal cells (Akazawa et al., 1994; Hartveit et al., 1995). Although mGluR7 has been shown to inhibit forskolin-stimulated 


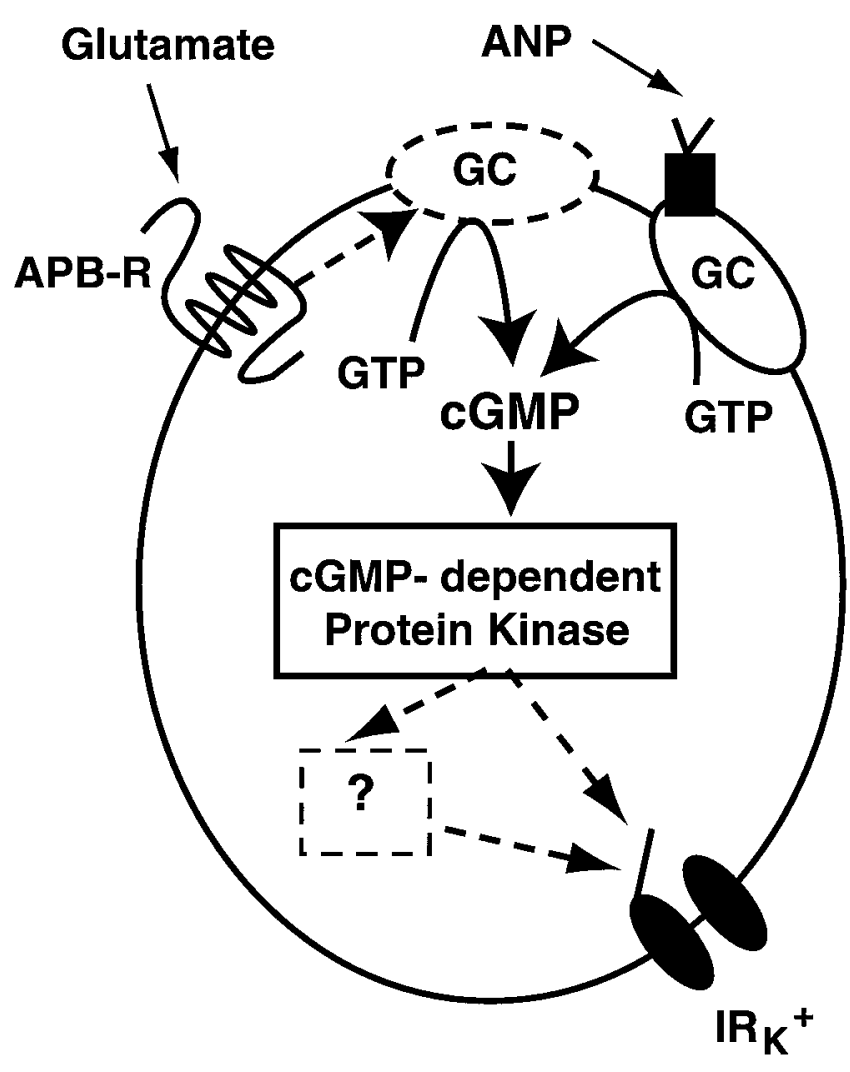

Figure 7. Model of glutamate-mediated $\mathrm{IR}_{\mathrm{K}}{ }^{+}$suppression. The simplest scheme consistent with the present data indicates that the APB receptor activates a membrane-bound guanylyl cyclase, thereby increasing intracellular cGMP. cGMP activates a protein kinase that may directly phosphorylate the $\mathrm{IR}_{\mathrm{K}}{ }^{+}$channel; however it is possible that one or more intermediaries is involved. Nevertheless, the result of increased cGMP is a closure of $\mathrm{IR}_{\mathrm{K}}{ }^{+}$channels. The dashed arrow and dashed border around $G C$ signify the hypothesized pathway by which the APB receptor upregulates the activity of a membrane-bound guanylyl cyclase. The dashed arrows between the kinase and the $\mathrm{IR}_{\mathrm{K}}{ }^{+}$channel signify that the site(s) of action of the kinase has not been established. The dashed box denotes one or more hypothetical intermediate steps, such as activation of a phosphatase, between the cGMP-dependent kinase and $\mathrm{IR}_{\mathrm{K}}{ }^{+}$.

cAMP formation in stably transfected kidney cells, it has been suggested, based on the required high agonist concentrations, that inhibition of adenylyl cyclase may not be the predominant signaling mechanism for mGluR7 (Saugstad et al., 1994). It is reasonable to consider the likelihood that one or more of the elements for a cGMP pathway, described here for the horizontal cells, were not present in the kidney cells used for the expression studies. Based on present data and confirmation that homologs of rat mGluRs are distributed similarly in catfish retina, it would seem that either mGluR7 or some as yet unidentified mGluR subtype mediates the suppression of $\mathrm{IR}_{\mathrm{K}}{ }^{+}$in catfish horizontal cells.

\section{Functional consequences of $\mathrm{IR}_{\mathbf{K}}{ }^{+}$modulation}

The rate of glutamate release from photoreceptors is the major determinant of the membrane potential in horizontal cells. Although glutamate may alter the amplitude of outward current through $\mathrm{IR}_{\mathrm{K}}{ }^{+}$at resting membrane potential in darkness or in moderate light (Figs. 1, 2), this effect would be minimal compared with the current flowing through the ionotropic glutamate channels. More pronounced effects of the modulation of $\mathrm{IR}_{\mathrm{K}}{ }^{+}$would be observed in the kinetics of light-evoked responses. The mag- nitude of $\mathrm{IR}_{\mathrm{K}}{ }^{+}$should regulate the transience of light-evoked responses in horizontal cells. Hence, light-induced changes in glutamate release from photoreceptors could regulate the transience by affecting $\mathrm{IR}_{\mathrm{K}}{ }^{+}$. Dong and Werblin (1995) provide evidence that $\mathrm{IR}_{\mathrm{K}}{ }^{+}$speeds the onset of hyperpolarizing light responses in horizontal cells. Barnes and Hille (1989) show that light responses in photoreceptors that extend to potentials negative of the rectification potential of $\mathrm{IR}_{\mathrm{K}}{ }^{+}$are made more transient because of inward current flow in these channels that causes the membrane potential to depolarize. In darkness, when glutamate levels are highest, $\mathrm{IR}_{\mathrm{K}}{ }^{+}$will be smallest so the change in membrane potential during a light flash will tend to be slower and more likely to stay at a hyperpolarized plateau (i.e., be less transient; Barnes and Hille, 1989). Light responses superimposed on a moderate background of illumination, when ambient glutamate levels are presumably decreased, would be predictably faster and more transient because the magnitude of $\mathrm{IR}_{\mathrm{K}}{ }^{+}$would be greater. Recordings of light responses in intact retinas are consistent with these predictions. Response waveforms in horizontal cells are faster and more transient in light-adapted retinas (see, e.g., Ball and Baldridge, 1991).

The elegance of a modulatory mechanism that uses the excitatory neurotransmitter is that its action is strongest and focused where synaptic activity is highest. Furthermore, modulation could be graded as a function of the intensity of synaptic activity. In the retina, where input signals can vary by several orders of magnitude across the visual field, localized modulation at sites of higher activity can compress the dynamic range locally, whereas sensitivity in neighboring regions of lesser activity would be preserved. As mentioned above, most of the known mGluRs are selectively distributed throughout the retina (Hartveit et al., 1995; Pin and Duvoisin, 1995). Their distribution pattern is consistent with expression in subsets of cell types, which suggests they could play similar roles in other cell types, focusing a particular form of modulation in areas in which activity is highest.

Precedent exists for modulation of inward rectifiers by neurotransmitters other than glutamate. Both $I_{\mathrm{h}}$ and $I_{\mathrm{f}}$ are modulated in several systems. One example of $I_{\mathrm{h}}$ modulation is found in leech salivary gland (Wuttke and Berry, 1992). $I_{\mathrm{h}}$ is increased by serotonin, a putative neurotransmitter in that system, via a cAMPdependent mechanism. It is thought that the change in $I_{\mathrm{h}}$ contributes not only to shaping action potentials but also to a slow depolarization leading to repetitive firing patterns that determine secretion (Wuttke and Bery, 1992). It is of note that this inward rectifier is suppressed by cGMP and its analogs; however, it is not yet known what transmitter or neuromodulator uses this mechanism in this leech system. In cardiac tissue, muscarinic activation decreases $I_{\mathrm{f}}$ via a cAMP-dependent second messenger cascade (DiFrancesco and Mangoni, 1994). In the heart $I_{\mathrm{f}}$, an inward rectifier that conducts potassium and sodium almost equally well is an important determinant of slow depolarization leading to cardiac threshold. Muscarinic suppression of $I_{\mathrm{f}}$ results in a slowing of the heart rate. Clearly modulation of $\mathrm{IR}_{\mathrm{K}}{ }^{+}$values has substantial impact on intercellular and intracellular signaling. In horizontal cells, $\mathrm{IR}_{\mathrm{K}}{ }^{+}$is a prime determinant of membrane potential in the light and may also influence light response transients (Dong and Werblin, 1995). Because the effects of glutamate are relatively long-lived, $\mathrm{IR}_{\mathrm{K}}{ }^{+}$modulation could contribute to some aspects of retinal plasticity such as light and dark adaptation.

In summary, the $\mathrm{IR}_{\mathrm{K}}{ }^{+}$in horizontal cells is most similar to that described by Hagiwara and Takahashi (1974). $\mathrm{IR}_{\mathrm{K}}{ }^{+}$in horizontal 
cells is modulated by glutamate, the neurotransmitter released by photoreceptors (Copenhagen and Jahr, 1989). This action seems to be via an APB-type metabotropic receptor linked to a cGMP second messenger cascade. $\mathrm{IR}_{\mathrm{K}}{ }^{+}$modulation serves to influence the electrical behavior of horizontal cells that, in turn, provide a possible substrate for retinal plasticity.

\section{REFERENCES}

Ahmad I, Leinders-Zufall T, Kocsis JD, Shepherd GM, Zufall F, Barnstable CJ (1994) Retinal ganglion cells express a cGMP-gated cation conductance activatable by nitric oxide donors. Neuron 12:155-165.

Akazawa C, Ohishi H, Nakajima Y, Okamoto N, Shigemoto R, Nakanishi S, Mizuno N (1994) Expression of mRNAs of L-APB-sensitive metabotropic glutamate receptors (mGluR4, mGluR6, mGluR7) in the rat retina. Neurosci Lett 171:52-54.

Akopian A, Witkovsky P (1996) Activation of metabotropic glutamate receptors decreases a high-threshold calcium current in spiking neurons of the Xenopus retina. Vis Neurosci 13:549-557.

Ball AK, Baldridge WH (1991) Background illumination reduces horizontal cell receptive-field size in both normal and 6-hydroxydopaminelesioned goldfish retinas. Vis Neurosci 7:441-450.

Barnes S, Hille B (1989) Ionic channels of the inner segment of tiger salamander cone photoreceptors. J Gen Physiol 94:719-743.

Bockaert J, Pin J, Fagni L (1993) Metabotropic glutamate receptors: an original family of $\mathrm{G}$ protein-coupled receptors. Fundam Clin Pharmacol 7:473-485.

Butt E, Eigenthaler M, Genieser H-G (1994) (Rp)-8-pCPT-cGMPS, a novel cGMP-dependent protein kinase inhibitor. Eur J Pharmacol 269:265-268.

Chinkers M, Garbers D, Chang M-S, Lowe D, Chin H, Goeddel D, Schulz S (1989) A membrane form of guanylate cyclase is an atrial natriuretic peptide receptor. Nature 338:78-83.

Copenhagen DR, Jahr CE (1989) Release of endogenous excitatory amino acids from turtle photoreceptors. Nature 341:536-539.

DiFrancesco D, Mangoni M (1994) Modulation of single hyperpolarization-activated channels $\left(\mathrm{I}_{\mathrm{f}}\right)$ by cAMP in the rabbit sinoatrial node. J Physiol (Lond) 474:437-482.

Dixon DB, Takahashi K-I, Copenhagen DR (1993) L-Glutamate suppresses HVA calcium current in catfish horizontal cells by raising intracellular proton concentration. Neuron 11:267-277.

Dong CJ, Werblin FS (1995) The inward rectifying potassium conductance can accelerate the rate of onset of the light response in retinal horizontal cells. J Neurophysiol 74:2258-2265.

Doupnik CA, Davidson N, Lester HA (1995) The inward rectifier potassium channel family. Curr Opin Neurobiol 5:268-277.

Duda T, Goraczniak R, Sitaramayya A, Sharma R (1993) Cloning and expression of an ATP-regulated human retina C-type natriuretic factor receptor guanylate cyclase. Biochemistry 32:1391-1395.

Eckstein F (1985) Nucleoside phosphorothioates. Annu Rev Biochem 54:367-402.

Goy MF (1991) cGMP: the wayward child of the cyclic nucleotide family. Trends Neurosci 14:293-299.

Hagiwara S, Takahashi K (1974) The anomalous rectification and cation selectivity of the membrane of a starfish egg cell. J Membr Biol 18:61-80.

Hartveit E, Brandstätter JH, Wässle H (1995) Expression of the mRNA of seven metabotropic glutamate receptors (mGluR1 to 7) in the rat retina. An in situ hybridization study on tissue sections and isolated cells. Eur J Neurosci 7:472-1483.

Hille B (1992) Potassium channels and chloride channels. In: Ionic channels of excitable membranes, 2nd Edition, pp 115-139. Sunderland, MA: Sinauer.

Jane DE, Oittaway K, Sunter DC, Thomas NK, Watkins JC (1995) New phenylglycine derivatives with potent and selective antagonist activity at pre-synaptic glutamate receptors in neo-natal rat spinal cord. Neuropharmacology 34:851-856.

Kaneko A, Tachibana M (1985) Effects of L-glutamate on the anomalous rectifier potassium current in horizontal cells of Carassius auratus retina. J Physiol (Lond) 358:169-182.
Karwoski CJ, Newman EA, Shimazaki H, Proenza LM (1985) Lightevoked increases in extracellular $\mathrm{K}^{+}$in the plexiform layers of amphibian retinas. J Gen Physiol 86:189-213.

Katsuki S, Arnold W, Mittal C, Murad F (1977) Stimulation of guanylate cyclase by sodium nitroprusside, nitroglycerin and nitric oxide in various tissue preparations and comparison to the effects of sodium azide and hydroxylamine. J Cyclic Nucleotide Res 3:23-35.

Koulen P, Malitschek B, Kuhn R, Wässle H, Brandstätter JH (1996) Group II and group III metabotropic glutamate receptors in the rat retina: distributions and developmental expression patterns. Eur J Neurosci 8:2177-2187.

Liu Y, Lasater EM (1994) Calcium currents in turtle retinal ganglion cells. II. Dopamine modulation via cyclic AMP-dependent mechanism. J Neurophysiol 71:743-752.

Lu Z, MacKinnon R (1994) A conductance maximum observed in an inward rectifier potassium channel. J Gen Physiol 104:477-486.

Naka K-I, Carraway N (1975) Morphological and functional identifications of catfish retinal neurons. I. Classical morphology. J Neurophysiol 38:53-71.

Nakanishi S (1992) Molecular diversity of glutamate receptors and implications for brain function. Science 258:597-603.

Nawy S, Jahr CE (1990) Suppression by glutamate of cGMP-activated conductance in retinal bipolar cells. Nature 346:269-271.

Oakley II B, Steinberg RH (1982) Effects of maintained illumination upon $\left[\mathrm{K}^{+}\right]_{\mathrm{o}}$ in the subretinal space of the frog retina. Vision Res 22:767-773.

O’Dell TJ, Christensen BN (1989) Horizontal cells isolated from catfish retina contain two types of excitatory amino acid receptors. J Neurophysiol 61:1097-1109.

Palm D, Keil L, Sassani J, Severs W (1989) Immunoreactive atrial natriuretic peptide in the retina of rats and rabbits. Brain Res 504:142-144.

Perlman I, Knapp AG, Dowling JE (1988) Local superfusion modifies the inward rectifying potassium conductance of isolated retinal horizontal cells. J Neurophysiol 60:1322-1332.

Pfeiffer-Linn CL, Perlman I, Lasater EM (1995) Sodium dependency of the inward potassium rectifier in horizontal cells isolated from the white bass retina. Brain Res 70:81-88.

Pin JP, Duvoisin R (1995) The metabotropic glutamate receptors: structure and functions. Neuropharmacology 34:1-26.

Rieke F, Schwartz EA (1994) A cGMP-gated current can control exocytosis at cone synapses. Neuron 13:863-873.

Saugstad JA, Kinzie JM, Mulvihill ER, Segerson TP, Westbrook GL (1994) Cloning and expression of a new member of the L-2-amino-4phosphonobutyric acid-sensitive class of metabotropic glutamate receptors. Mol Pharmacol 45:367-372.

Shabb JB, Corbin JD (1992) Cyclic nucleotide-binding domains in proteins having diverse functions. J Biol Chem 267:5723-5726.

Shiells RA, Falk G (1990) Glutamate receptors of rod bipolar cells are linked to a cyclic GMP cascade via a G-protein. Proc R Soc Lond [Biol] 242:91-94.

Shingai R, Christensen BN (1986) Excitable properties and voltagesensitive ion conductances of horizontal cells isolated from catfish (Ictalurus punctatus) retina. J Neurophysiol 56:32-49.

Tachibana M (1983) Ionic currents of solitary horizontal cells isolated from goldfish retina. J Physiol (Lond) 345:329-351.

Taglialetla M, Flicker E, Wible BA, Brown AM (1995) C-terminus determinants for $\mathrm{Mg}^{2+}$ and polyamine block of the inward rectifier $\mathrm{K}^{+}$ channel IRK1. EMBO J 14:5532-5541.

Takahashi K-I, Copenhagen DR (1995) Intracellular alkalinization enhances inward rectifier $\mathrm{K}^{+}$current in retinal horizontal cells of Catfish. Zool Sci 12:29-34.

White RE, Darkow DJ, Lang JL (1995) Estrogen relaxes coronary arteries by opening BKCa channels through a cGMP-dependent mechanism. Circ Res 77:936-942.

Wuttke WA, Berry MS (1992) Modulation of inwardly rectifying $\mathrm{Na}^{+}-\mathrm{K}^{+}$channels by serotonin and cyclic nucleotides in salivary gland cells of the leech, Haementeria. J Membr Biol 127:57-68. 